Journal of Plant Production

Journal homepage: www.jpp.mans.edu.eg

Available online at: www.jpp.journals.ekb.eg

\title{
Evaluation of New Popcorn Hybrids under Two Plant Densities
}

\section{El-Gazzar, I. A. I.*}

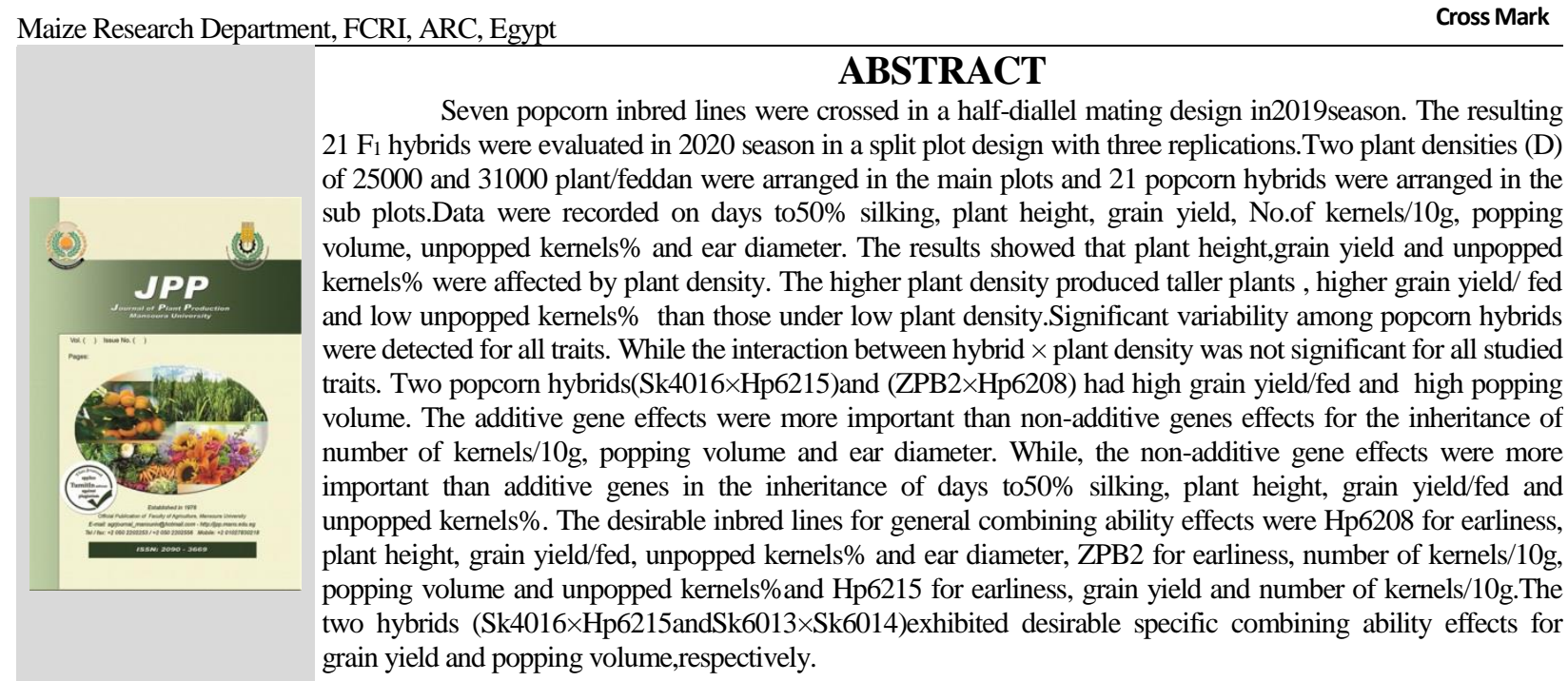

Keywords: Diallel cross, Additive gene effects, Non-additive gene effects, Popcorn, Popping volume.

\section{INTRODUCTION}

Popcorn (Zea mays L. everta) is essentially a flint type of maize grown by native Indians in south, central and North America. The spread and distribution of maize in other parts of the world resulted in increased production, consumption and popularity of popcorn. In Egypt as a result of increasing the demand for consumption of popcorn, hence it is imported from foreign countries. So, the price of popcorn in Egypt is higher four times or more than that of common corn grain (Mosa et al. 2019). Not only genetic potential of hybrid (Halluer, 1994), but also cultural practices such as nitrogen fertilizer rates and plant densities have important effects on popcorn yield (Babic and Pajic, 1992). Optimum plant density is another important factor for high grain yield. Yield can be increased with increased plant density up to a maximum for some maize genotypes grown under a set of particular environment a management is increased further (Sezer and Yanbeyi 1997). Demonstrated that ear characteristics were negatively affected by increases in plant densities, although plant height and grain yield increased with increases in plant densities. Popping volume, defined as volume per unit of weight of a sample, is a primary characteristic of popcorn. The popping volume is highly depending on the chemical composition of the kernel, mostly the proportion of hard endosperm. Also the main indicators for popcorn popping volume are the percentage or number of unpopped kernels and grain moisture content at the time of popping. The grain moisture content of kernels is an important factor for high popping volume. Kernels contain a small amount of water stored in a circle of soft starch inside the hard outer surface. When heated the water expands, creating pressure within, until eventually, the casing gives way and the kernels explode and pop, allowing the water to escape as steam, turning the kernels inside out (Anon, 2007). Maximum popping volume was achieved with a grain moisture content ranging from 13 to $14.5 \%$, with $13.5 \%$ being optimum (Ziegler et al. 1988). The quality factors include the percentage of unpopped kernels, size, and other traits (Ziegler, 2001 and Quinn et al. 2005). High yielding popcorn cultivars usually produce low popping volume. Whereas higher popping volume were recorded for low or medium yielding cultivars (Pajic et al. 2008). Diallel crosses analysis provide information regarding the general and specific combining ability of a set of genotypes, allowing reliable inference of the best hybrid combinations (Hallauer et al. 2010). The best strategy for simultaneously improving yield and expansion capacity would be to use material with good expansion capacity and then select plants with more than one ear (Broccoli and Burak 2004). Also path analysis revealed that cob weight showed very high positive direct effect on popping expansion followed by plant height, days to maturity and to $50 \%$ silking (Vijayabharathi et al. 2009). Babić and Pajic (1992) and Halluer (1994) mentioned that not only genetic potential of hybrid but also cultural practices such plant density have important effects on popcorn yield. Ülger (1998) demonstrated that highest popcorn yield obtained with planting $15 \mathrm{~cm}$ intra-row and $70 \mathrm{~cm}$ inter-row spacing. Sezer and Yanbeyi (1997) reported that ear traits were negatively affected by increases in plant densities, although plant height and grain yield increased with increasing plant density. Junior et al. (2013) found that the increase in plant 
population causes a reduction in the number of grains per ear, but the popping volume index is not affected by row spacing or plant population. Miranda et al. (2008) and Pajic et al. (2008) concluded that additive gene effects were more important than non- additive effects for popping volume. Jele et al. (2014) found that the additive gene effects were more prominent than non- additive effects for unpopped kernels, moisture content and kernels/10g. Oliveira et al. (2019) found that the non- additive effects were the most important in the genetic control of grain yield and popping volume. This study aimed to evaluate the combining ability variances and effects for seven traits under two plant density levels and identify hybrids with greater potential for seed quality and superior agronomic traits to meet the increased demand on popcorn in Egypt.

\section{MATERIALS AND METHODS}

Seven yellow popcorn inbred lines in the selfing generation $\mathrm{S}_{6}$ developed from the seven popcorn populations at Sakha Research Station were crossed in a half- diallel mating design according to Griffing's method 4 to generate $21 \mathrm{~F}_{1}$ crosses in 2019 season. The resulting 21 hybrids were arranged in a split plot design with three replications. Main plots included two plant density of 25000 and 31000 plant per feddan (feddan $=4200 \mathrm{~m}^{2}$ ), while sub plots included 21 hybrids in 2020 growing season. Each plot consisted of one row, $6 \mathrm{~m}$ long, distance between rows with $0.8 \mathrm{~m}$ width and $21 \mathrm{~cm}$ between hills in first density and $17.5 \mathrm{~cm}$ between hills in second density. The hybrids were managed using standard production practices recommended for maize in Egypt. The data were recorded on days to $50 \%$ silking, plant height $(\mathrm{cm})$, ear diameter $(\mathrm{cm})$ and grain yield expressed in ardab/feddan ( $\mathrm{ard} / \mathrm{fed})(\mathrm{ardab}=140 \mathrm{~kg}$ ) adjusted at $15.5 \%$ grain moisture. Popping traits taken on a grain sample from each plot were kernel size determined by number of kernels per $10 \mathrm{~g}$, for each classification of kernels, i.e. for large size (52-67), medium size (68-75) and small size (76-105), popping volume measured by placing $30 \mathrm{~g}$ of grain in hot air popping machine (Volt: $220 \mathrm{v}, \mathrm{Hz}: 50 \mathrm{~Hz}$, power: $1200 \mathrm{w}$ ) for 2 minutes, then the popcorn volume was measured in a $2000 \mathrm{ml}$ graduated cylinder and finally the popping volume was determined as the ratio between the expanded popcorn volume and the weight of $30 \mathrm{~g}$ of grains $(\mathrm{ml} / \mathrm{g})$ and percentage of unpopped kernels measured by dividing number of unpopped kernels on the original number of kernels in $30 \mathrm{~g}$. Statistical analysis for all trails was done according to Steel and Torrie (1980). General and specific combining ability were estimated according to Griffing (1956) diallel cross analysis designated as Method 4 model 1 (fixed model).

\section{RESULTS AND DISCUSSION}

Analysis of variance for seven traits is shown in Table 1. The effects of plant density (D) on plant height, grain yield and unpopped kernels $\%$ were significant or highly significant. While, days to $50 \%$ silking, No. of kernels/10g, popping volume and ear diameter were not affected by plant density. Also, significant differences among popcorn hybrids $(\mathrm{H})$ were detected for all studied traits. While the interaction between $\mathrm{H} \times \mathrm{D}$ was not significant for all studied traits. Same results were obtained by Jele et al. (2014) and Mosa et al. (2019).

Table 1. Mean squares from analysis of variance for seven traits.

\begin{tabular}{|c|c|c|c|c|c|c|c|c|}
\hline SOV & df & $\begin{array}{c}\text { Days to } \\
50 \% \\
\text { silking }\end{array}$ & $\begin{array}{c}\text { Plant } \\
\text { height } \\
\text { (cm) }\end{array}$ & $\begin{array}{c}\text { Grain } \\
\text { yield } \\
\text { (ard/fed) }\end{array}$ & $\begin{array}{c}\text { No. } \\
\text { of kernels/ } \\
10 \mathrm{~g}\end{array}$ & $\begin{array}{l}\text { Popping } \\
\text { volume } \\
\text { (ml/g) }\end{array}$ & $\begin{array}{c}\text { Unpopped } \\
\text { kernels } \\
(\%)\end{array}$ & $\begin{array}{c}\text { Ear } \\
\text { diameter } \\
(\mathbf{c m})\end{array}$ \\
\hline Rep & 2 & 2.214 & 164.21 & 71.457 & 28.917 & 57.434 & 6.94 & 0.018 \\
\hline Density (D) & 1 & 0.007 & $1905.5^{*}$ & $306.50 * *$ & 23.383 & 4.089 & $9.895 * *$ & 0.040 \\
\hline Error (a) & 2 & 6.912 & 42.72 & 1.923 & 4.988 & 0.551 & 0.100 & 0.004 \\
\hline Hybrid $(\mathrm{H})$ & 20 & $17.02 * *$ & $400.2 * *$ & $125.04 * *$ & $61.542 * *$ & $71.901 * *$ & $3.49 * *$ & $0.148^{* *}$ \\
\hline $\mathrm{H} \times \mathrm{D}$ & 20 & 2.29 & 31.42 & 2.04 & 5.926 & 4.983 & 1.388 & 0.020 \\
\hline Error (b) & 80 & 1.47 & 58.98 & 5.62 & 7.33 & 7.139 & 0.906 & 0.032 \\
\hline
\end{tabular}

*,** significant at 0.05 and 0.01 levels of probability, respectively.

The results in Table 2, exhibited that the higher plant density (31000 plant/fed) produced taller plants, higher grain yield/fed and low unpopped kernels \% than those under low plant density (25000 plant/fed). Gözübenli and
Konuskan (2010) concluded that plant height and grain yield increased with increases in plant density. Junior et al (2013) demonstrated that the popping expansion index is not affected by plant density.

Table 2. Effects of plant density on the seven studied traits.

\begin{tabular}{lccccccc}
\hline Density & $\begin{array}{c}\text { Days to } \\
\mathbf{5 0 \%} \\
\text { silking }\end{array}$ & $\begin{array}{c}\text { Plant } \\
\text { height } \\
(\mathbf{c m})\end{array}$ & $\begin{array}{c}\text { Grain } \\
\text { yield } \\
\text { (ard/fed) }\end{array}$ & $\begin{array}{c}\text { No. of } \\
\text { kernels/ } / \mathbf{1 0 g}\end{array}$ & $\begin{array}{c}\text { Popping } \\
\text { volume } \\
(\mathbf{m l} / \mathbf{g})\end{array}$ & $\begin{array}{c}\text { Unpopped } \\
\text { kernels } \\
(\mathbf{\%})\end{array}$ & $\begin{array}{c}\text { Ear } \\
\text { diameter } \\
(\mathbf{c m})\end{array}$ \\
\hline 25000 plant/fed & 68.41 & 223.49 & 16.31 & 62.55 & 31.86 & 3.77 & 3.20 \\
31000 plant/fed & 68.39 & 231.26 & 19.43 & 61.69 & 32.22 & 3.21 & 3.17 \\
LSD 0.05 & 2.015 & 5.011 & 1.063 & 1.712 & 0.569 & 0.242 & 0.048 \\
0.01 & 4.649 & 11.559 & 2.452 & 3.949 & 1.312 & 0.559 & 0.111 \\
\hline
\end{tabular}

Mean performance of 21 popcorn hybrids for seven studied traits is presented in Table 3. Means of days to 50\% silking ranged from 66 days for Sk4017×Hp6215 to 73.3 days for Sk4017×Sk6014 with a grand mean of 68.4 days, the best hybrids for earliness were Sk4016 $\times$ Hp6208, Sk4017×Hp6208，Sk4017×Hp6215，ZPB2×Hp6208 and Hp6215×Sk6013.

For plant height $(\mathrm{cm})$, the means ranged from 213.5 to $240 \mathrm{~cm}$ for Sk4017×Hp6208 and Hp6208 × Hp6215, respectively, with a grand mean of $227.3 \mathrm{~cm}$. The shortest hybrids were Sk4017 × Hp6208, Sk4017 × Sk6013, ZPB2 × Hp6208 and Hp6208×Sk6013, while the tallest hybrids were ZPB2 $\times$ Sk6013, ZPB2 $\times$ Sk6014, Hp6208 $\times$ Hp6215 and Hp6215×Sk6014.

The mean of 21 popcorn hybrids for grain yield ranged from $10.7 \mathrm{ard} / \mathrm{fed}$ for $\mathrm{Sk} 4016 \times$ Sk6013 to 23.4 ard/fed for Hp6208×Hp6215 with a grand mean of 17.8 ard/fed. The higher hybrids for grain yield were Hp6208 
$\times$ Hp6215 (23.4 ard/fed), Sk4016 × Hp6215 (23.3 ard/fed), ZPB2 × Hp6208 (23.2 ard/fed), Hp6215 × Sk6013 (22.8 $\mathrm{ard} / \mathrm{fed}), \mathrm{Sk} 4017 \times \mathrm{Hp} 6208$ (22.7 ard/fed), Hp6208×Sk6014 (22.4 ard/fed) and Sk4016×Hp6208 (21.5 ard/fed). Generally, a popcorn ear is significantly smaller than ear of other types of maize; it's means give us the leads to a decrease in the production of popcorn grain yield. Followed by Oliveira et al (2019) reported that the average grain yield of popcorn hybrids ranged from 321.26 to $4496.31 \mathrm{~kg} / \mathrm{ha}$.

Table 3. Mean performance of 21 popcorn hybrids for seven studied traits.

\begin{tabular}{|c|c|c|c|c|c|c|c|}
\hline Hybrids & $\begin{array}{l}\text { Days to } \\
50 \% \\
\text { silking }\end{array}$ & $\begin{array}{c}\text { Plant } \\
\text { height } \\
\text { (cm) }\end{array}$ & $\begin{array}{c}\text { Grain } \\
\text { yield } \\
\text { (ard/fed) }\end{array}$ & $\begin{array}{c}\text { No. of } \\
\text { kernels/ } \\
10 \mathrm{~g}\end{array}$ & $\begin{array}{c}\text { Popping } \\
\text { volume } \\
(\mathrm{ml} / \mathrm{g})\end{array}$ & $\begin{array}{c}\text { Unpopped } \\
\text { kernels } \\
(\%)\end{array}$ & $\begin{array}{c}\text { Ear } \\
\text { diameter } \\
(\mathrm{cm})\end{array}$ \\
\hline Sk4016 × Sk4017 & 69.3 & 228.5 & 13.5 & 64.6 & 33.33 & 8.6 & 3.3 \\
\hline$\times \mathrm{ZPB} 2$ & 67.8 & 236.6 & 13.9 & 68.4 & 37.5 & 8 & 2.9 \\
\hline$\times$ Hp6208 & 67.0 & 229.6 & 21.5 & 60 & 31.38 & 6 & 3.3 \\
\hline$\times$ Hp6215 & 67.3 & 229.6 & 23.3 & 63 & 31.88 & 7 & 3.2 \\
\hline$\times$ Sk6013 & 68 & 225.8 & 10.7 & 61.6 & 34.22 & 8.5 & 2.9 \\
\hline$\times$ Sk6014 & 70.1 & 227.5 & 12.6 & 61.6 & 35.44 & 7.6 & 3.0 \\
\hline Sk4017 × ZPB2 & 68.1 & 229.6 & 16.5 & 62.7 & 37.5 & 6.8 & 3.2 \\
\hline$\times$ Hp6208 & 67 & 213.5 & 22.7 & 61.5 & 26.22 & 5.5 & 3.4 \\
\hline$\times$ Hp6215 & 66 & 218.6 & 20.1 & 61.1 & 28.83 & 5.6 & 3.3 \\
\hline$\times$ Sk6013 & 70.8 & 217.1 & 11.3 & 56.2 & 32.22 & 7.1 & 3.4 \\
\hline$\times$ Sk6014 & 73.3 & 225.1 & 11.4 & 57.7 & 31.83 & 7.3 & 3.3 \\
\hline ZPB2 × Hp6208 & 67 & 216.6 & 23.2 & 62.3 & 30.27 & 3.6 & 2.9 \\
\hline$\times \mathrm{Hp} 6215$ & 67.5 & 226.5 & 17.7 & 64.7 & 30.27 & 5.8 & 2.9 \\
\hline$\times$ Sk6013 & 68 & 237.5 & 17.6 & 62 & 34.72 & 4.8 & 3.1 \\
\hline$\times$ Sk6014 & 69.8 & 239.1 & 16.8 & 63.2 & 32.85 & 6.6 & 3.0 \\
\hline Нp6208 × Нp6215 & 68 & 240 & 23.4 & 66.8 & 29.83 & 7.8 & 3.2 \\
\hline$\times$ Sk6013 & 67.8 & 214.6 & 19.2 & 40.9 & 25.55 & 5 & 3.2 \\
\hline × Sk6014 & 69.5 & 222.1 & 22.4 & 41.8 & 30.16 & 3.5 & 3.2 \\
\hline Hp6215 × Sk6013 & 66.8 & 227.1 & 22.8 & 61.5 & 27.77 & 6.1 & 3.3 \\
\hline$\times$ Sk6014 & 67.5 & 239.1 & 21.0 & 65.1 & 33.38 & 7 & 3.1 \\
\hline Sk6013 × Sk6014 & 69.5 & 230 & 12.7 & 59.1 & 37.77 & 8.1 & 3.2 \\
\hline Grand mean & 68.4 & 227.3 & 17.8 & 60.2 & 32.04 & 6.5 & 3.2 \\
\hline LSD 0.05 & 1.38 & 8.77 & 2.70 & 3.09 & 3.054 & 1.08 & 0.204 \\
\hline 0.01 & 1.82 & 11.57 & 3.56 & 4.07 & 3.979 & 1.43 & 0.269 \\
\hline
\end{tabular}

Number of kernels/ $10 \mathrm{~g}$ indicates the size of kernel. The means ranged from 40.9 for $\mathrm{Hp6208} \times \mathrm{Sk6013}$ to 68.4 for Sk4016×ZPB2 with an average of 60.2 kernels/10g, meaning that all hybrids had a large size, except the hybrid Sk4016×ZPB2 was medium. Lin and Anantheswaran (1988) reported that the large-sized kernels had a significantly higher popping volume than the small sized kernels. Although, Song et al. (1991) found that the middle sized kernels had the highest popping volume. Popping volume ranged from 25.55 to $37.77 \mathrm{ml} / \mathrm{g}$ for Hp6208×Sk6013 and Sk6013×Sk6014, respectively, with a grand mean of $32.04 \mathrm{ml} / \mathrm{g}$. The highest popcorn hybrids for popping volume were Sk6013×Sk6014, followed by Sk4016×ZPB2, Sk4017×ZPB2, Sk4016× Sk6014, ZPB2× Sk6013, Sk4016 ×Sk6013 and Hp6215× Sk6014. Song et al. (1991) found that popping volume is one of the primary measures of pop ability, since commercial buyers purchase popcorn by weight and sell by bulk volume. Oliveira et al. (2019) found that the popping expansion ranged from 11.8 to 56 $\mathrm{ml} / \mathrm{g}$, while Junior et al. (2013) observed popping volume of an average of $31 \mathrm{ml} / \mathrm{g}$. Percentage of unpopped kernels is one of the most important quality traits. The means ranged from 3.5 to $8.6 \%$ for Hp6208×Sk6014 and Sk4016×Sk4017, respectively, with an average of $6.5 \%$. The desirable hybrids which had lowest unpopped kernels \% were Hp6208 × Sk6014,ZPB2 × Hp6208,ZPB2×Sk6013,Hp6208×Sk6013, Sk4017 × Hp6208 and Sk4017 $\times$ Hp6215. Song et al. (1991) found that popcorn hybrids and kernels size were significantly affected the percentage of unpopped kernels. Öz and Kapar (2011) found that the unpopped kernels ranged from 2.8 to $10.1 \%$. Ear diameter ranged from $2.9 \mathrm{~cm}$ to $3.4 \mathrm{~cm}$ for Sk4016× Sk6013 and Sk4017 $\times$ Hp6208, respectively, with a grand mean of $3.2 \mathrm{~cm}$. The highest popcorn hybrids for ear diameter were
Sk4017 × Hp6208, Sk4017 × Sk4016, Sk4016 × Hp6208, Sk4017×Hp6215 and Sk6215×Sk6013. to $56 \mathrm{ml} / \mathrm{g}$. In general, from previous results the two popcorn hybrids Sk4016×Hp6215 and ZPB2 $\times$ Hp6208 had high grain yield/fed and popping volume.

The mean squares of general and specific combining ability and their interactions with two plant densities for seven traits are presented in Table 4. Mean squares due to general combining ability (GCA) and specific combining ability (SCA) were highly significant for all studied traits, except (SCA) for ear diameter which was significant and the interactions with plant densities $(\mathrm{GCA} \times \mathrm{D})$ and $(\mathrm{SCA} \times$ D ) which were not significant for all studied traits, except for GCA $\times$ D for days to $50 \%$ silking which was significant. The magnitude of $\mathrm{K}^{2} \mathrm{GCA}$ was higher relative to $\mathrm{K}^{2} \mathrm{SCA}$ for number of kernels/10g, popping volume, and ear diameter, meaning that the additive gene effects were more important than non -additive gene effects for inheritance of these traits. Similar results were obtained by Pereira and Amaral Junjor (2001) and Jele et al. (2014), who indicated the predominance of additive effects for popping volume. Rangel et al. (2008) and Silva et al. (2010) reported that GCA and SCA were significant for grain yield and popping volume, suggesting the existence of additive and non additive effects in the genetic control of these traits. Larish et al. (1999), Pereira and Amaral Júnior (2001) and Li et al. (2007) found that the additive gene effects were more important in the expression of popping volume, Jele et al. (2014) found that the additive gene effects were more prominent than non-additive gene effects for number of kernels/10g. 
Table 4. Mean squares of general and specific combining ability and their interactions with two plant densities for seven traits.

\begin{tabular}{|c|c|c|c|c|c|c|c|c|}
\hline SOV & df & $\begin{array}{l}\text { Days to } \\
50 \% \\
\text { silking }\end{array}$ & $\begin{array}{c}\text { Plant } \\
\text { height } \\
\text { (cm) }\end{array}$ & $\begin{array}{c}\text { Grain } \\
\text { yield } \\
\text { (ard/fed) }\end{array}$ & $\begin{array}{c}\text { No. } \\
\text { of kernels/ } \\
10 \mathrm{~g}\end{array}$ & $\begin{array}{l}\text { Popping } \\
\text { volume } \\
\text { (ml/g) }\end{array}$ & $\begin{array}{c}\text { Unpopped } \\
\text { kernels } \\
(\%)\end{array}$ & $\begin{array}{c}\text { Ear } \\
\text { diameter } \\
(\mathbf{c m})\end{array}$ \\
\hline$\overline{\mathrm{GCA}}$ & 6 & $36.24 * *$ & $641.82 * *$ & $225.95 * *$ & $132.168 * *$ & $159.876^{* *}$ & $9.84^{* *}$ & $0.372 * *$ \\
\hline SCA & 14 & $8.76 * *$ & $296.7 * *$ & $81.426 * *$ & $31.278 * *$ & $34.2 * *$ & $1.992 * *$ & $0.054 *$ \\
\hline $\mathrm{GCA} \times \mathrm{D}$ & 6 & $3.81 *$ & 55.73 & 3.597 & 6.294 & 7.227 & 1.953 & 0.024 \\
\hline $\mathrm{SCA} \times \mathrm{D}$ & 14 & 1.641 & 21.015 & 1.374 & 5.766 & 4.02 & 1.152 & 0.018 \\
\hline Error & 80 & 1.47 & 58.98 & 5.62 & 7.33 & 7.139 & 0.906 & 0.032 \\
\hline $\mathrm{K}^{2} \mathrm{GCA} / \mathrm{K}^{2} \mathrm{SCA}$ & - & 0.33 & 0.30 & 0.463 & 1.56 & 1.92 & 0.06 & 1.01 \\
\hline
\end{tabular}

*, ** significant at 0.05 and 0.01 levels of probability, respectively.

The results in Table 5, exhibited that the desirable general combining ability (GCA) effects were obtained by the inbred lines, Hp6208, Hp6215 and ZPB2 for earliness, Sk4017 and Hp6208 for short plant, Hp6208 and Hp6215 for grain yield, Sk4016, ZPB2 and Hp6215 for high number of kernels/10g, Sk4016, ZPB2 and Sk6014 for popping volume, Hp6208 and ZPB2 for unpopped kernels\% and Sk4017 and Hp6208 for ear diameter.

Table 5. Estimates of general combing ability effects of seven inbred lines for seven traits.

\begin{tabular}{|c|c|c|c|c|c|c|c|}
\hline Lines & $\begin{array}{c}\text { Days to } \\
50 \% \\
\text { silking } \\
\end{array}$ & $\begin{array}{c}\text { Plant } \\
\text { height } \\
\text { (cm) }\end{array}$ & $\begin{array}{c}\text { Grain } \\
\text { yield } \\
\text { (ard/fed) }\end{array}$ & $\begin{array}{l}\text { No. } \\
\text { of kernels/ } \\
10 \mathrm{~g}\end{array}$ & $\begin{array}{l}\text { Popping } \\
\text { volume } \\
(\mathrm{ml} / \mathrm{g})\end{array}$ & $\begin{array}{c}\text { Unpopped } \\
\text { kernels } \\
(\%) \\
\end{array}$ & $\begin{array}{c}\text { Ear } \\
\text { diameter } \\
(\mathrm{cm})\end{array}$ \\
\hline Sk4016 & -0.152 & $2.709 * *$ & $-2.313^{* *}$ & $6.719 * *$ & $2.298 * *$ & $1.338^{* *}$ & $-0.059 *$ \\
\hline $\mathrm{Sk} 4017$ & $0.847 * *$ & $-6.323 * *$ & $-2.283 * *$ & $-5.181 * *$ & -0.468 & 0.404 & $0.183 * *$ \\
\hline ZPB2 & $-0.419 *$ & $4.376 * *$ & -0.220 & $6.485^{* *}$ & $2.165 * *$ & $-0.661 *$ & $-0.192 * *$ \\
\hline Нp6208 & $-0.819 * *$ & $-5.523 * *$ & $5.076 * *$ & $-3.514 * *$ & $-3.76 * *$ & $-1.528 * *$ & $0.057 *$ \\
\hline Hp6215 & $-1.452 * *$ & $3.376 * *$ & $4.286 * *$ & $5.785^{* *}$ & $--2.057 * *$ & 0.071 & 0.0005 \\
\hline Sk6013 & 0.114 & -2.39 & $-2.537 * *$ & $-8.681 * *$ & -0.002 & 0.138 & 0.030 \\
\hline Sk6014 & $1.881 * *$ & $3.776 * *$ & $-2.007 * *$ & -1.614 & $1.831 * *$ & 0.238 & -0.0195 \\
\hline $\operatorname{LSD~g}_{\mathrm{ij}} \quad 0.05$ & 0.405 & 2.570 & 0.791 & 2.661 & 0.893 & 0.596 & 0.057 \\
\hline 0.01 & 0.528 & 3.349 & 1.031 & 3.468 & 1.164 & 0.777 & 0.075 \\
\hline LSD $\mathrm{g}_{\mathrm{i}^{-}} \mathrm{g}_{\mathrm{i}} 0.05$ & 0.619 & 5.115 & 1.209 & 4.065 & 1.365 & 0.911 & 0.088 \\
\hline 0.01 & 0.807 & 6.666 & 1.576 & 5.297 & 1.779 & 1.187 & 0.115 \\
\hline
\end{tabular}

*, ** significant at 0.05 and 0.01 levels of probability, respectively.

The best hybrids for specific combing ability effects of 21 hybrid for seven traits is shown in Table 6. The most desirable hybrid was Sk4017×Hp6208 for earliness, grain yield and number of kernels/10g, Sk4017×Hp6215 for earliness, plant height and Popping volume kernels\%, Sk4016 $\times$ Sk6014 for plant height and number of kernels/10g, Hp6208×Hp6215 for number of kernels/10g and popped volume, Sk6013× Sk6014 for earliness and popping volume, ZPB2 $\times$ Hp6208 and Sk6215× Sk6014 for earliness, Hp6215× Sk6013, ZPB2× Sk6013and Sk4016× Hp6215 for grain yield, Hp6208×Sk6014 for unpopped kernels\%, and Sk4016×Hp6208 for ear diameter. These popcorn hybrids will be tested in advanced trails for further evaluation.

Table 6. The specific combing ability effects of 21 hybrid for seven traits.

\begin{tabular}{|c|c|c|c|c|c|c|c|}
\hline cross & $\begin{array}{l}\text { Days to } 50 \% \\
\text { silking }\end{array}$ & $\begin{array}{l}\text { Plant height } \\
\text { (cm) }\end{array}$ & $\begin{array}{c}\text { Grain } \\
\text { yield } \\
\text { (ard/fed) }\end{array}$ & $\begin{array}{l}\text { No. of } \\
\text { kernels/ } \\
10 \mathrm{~g}\end{array}$ & $\begin{array}{l}\text { Popping } \\
\text { volume } \\
(\mathrm{ml} / \mathrm{g})\end{array}$ & $\begin{array}{c}\text { Unpopped } \\
\text { kernels } \\
(\%)\end{array}$ & 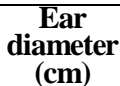 \\
\hline Sk4016 × Sk4017 & 0.233 & 4.733 & 0.244 & $6.089 *$ & -0.545 & 0.4 & 0.034 \\
\hline$\times \mathrm{ZPB} 2$ & 0.00 & 2.200 & -1.419 & $5.756^{*}$ & 0.989 & 0.8 & 0.011 \\
\hline$\times$ Hp6208 & -0.433 & $5.100 *$ & 0.868 & $-9.578 * *$ & 0.811 & -0.333 & $0.161 * *$ \\
\hline$\times \mathrm{Hp} 6215$ & 0.533 & -3.800 & $3.541 * *$ & $-9.878 * *$ & -0.40 & -0.933 & 0.084 \\
\hline$\times$ Sk6013 & -0.367 & -1.867 & $-2.302 *$ & 0.589 & -0.122 & 0.5 & $-0.212 * *$ \\
\hline$\times$ Sk6014 & 0.033 & $-6.367 *$ & -0.932 & $7.022 * *$ & -0.732 & -0.433 & -0.078 \\
\hline $\mathrm{Sk} 4017 \times \mathrm{ZPB} 2$ & -0.667 & 4.233 & 1.218 & 0.489 & $3.756 * *$ & 0.567 & 0.034 \\
\hline$\times \mathrm{Hp} 6208$ & $-1.433 * *$ & -2.033 & $2.121 * *$ & $6.989 * *$ & -1.589 & 0.1 & -0.015 \\
\hline$\times$ Hp6215 & $-1.800 * *$ & $-5.767 *$ & 0.294 & -3.644 & -0.69 & $-1.333 *$ & -0.075 \\
\hline$\times$ Sk6013 & $1.467 * *$ & -1.500 & -1.716 & -3.678 & 0.645 & 0.1 & 0.011 \\
\hline$\times$ Sk6014 & $2.200 * *$ & 0.333 & -2.162 & $-6.244 *$ & -1.577 & 0.167 & 0.011 \\
\hline ZPB2 $\times$ Hp6208 & -0.167 & $-9.567 * *$ & 0.558 & -2.344 & -0.167 & -0.667 & -0.105 \\
\hline$\times$ Hp6215 & $0.967 *$ & $-8.633 * *$ & $-4.152 * *$ & -4.478 & $-1.879 *$ & -0.1 & -0.048 \\
\hline$\times$ Sk6013 & -0.100 & $8.133 * *$ & $2.571 * *$ & 1.989 & 0.513 & -0.167 & 0.087 \\
\hline$\times$ Sk6014 & -0.033 & 3.633 & 1.224 & -1.411 & $-3.211 * *$ & 0.567 & 0.021 \\
\hline Нp6208 × Нp6215 & $1.867 * *$ & $14.767 * *$ & $-3.832 * *$ & $11.856 * *$ & $3.613 * *$ & $2.767 * *$ & -0.065 \\
\hline$\times$ Sk6013 & 0.133 & -4.800 & -1.209 & -1.344 & $-2.722 * *$ & -0.133 & -0.012 \\
\hline$\times$ Sk6014 & 0.033 & -3.467 & 1.494 & $-5.578 *$ & 0.055 & $-1.733 * *$ & 0.037 \\
\hline Hp6215 × Sk6013 & -0.233 & -1.200 & $3.214 * *$ & 1.189 & $-2.211 *$ & -0.567 & 0.111 \\
\hline$\times \mathrm{Sk} 6014$ & $-1.333 * *$ & 4.633 & 0.934 & 4.956 & 1.568 & 0.167 & -0.005 \\
\hline Sk6013 × Sk6014 & $-0.900 *$ & 1.233 & -0.559 & 1.256 & $3.898 * *$ & $1.267 *$ & 0.014 \\
\hline LSD $_{\mathrm{sij}} 0.05$ & 0.800 & 5.068 & 1.561 & 5.248 & 1.762 & 1.176 & 0.114 \\
\hline 0.01 & 1.042 & 6.604 & 2.034 & 6.839 & 2.297 & 1.533 & 0.148 \\
\hline $\mathrm{LSD}_{\mathrm{sij}}-\mathrm{S}_{\mathrm{kl}} 0.05$ & $1.07 \overline{3}$ & 6.800 & 2.095 & 7.041 & 2.365 & 1.579 & 0.153 \\
\hline $\begin{array}{rr}0.01 \\
\end{array}$ & 1.398 & 8.861 & 2.729 & 9.175 & 3.081 & 2.057 & 0.199 \\
\hline
\end{tabular}

*, ** significant at 0.05 and 0.01 levels of probability, respectively.

\section{REFERENCES}

Anon, Y. (2007). How popcorn pops. http://www. Popcorn. Org/ Frames. Cfm main $=$ /teachers/ index. Cf/manduser (accessed June 8, 2007).
Babic,M. and Z. Pajic (1992). Effect of genotype x environment interaction on popping volume in popcorn hybrids (Zea mays L.). Genetika 1:27-32. 
Broccoli, A.M. and R. Burak (2004). Effects of genotype $\times$ environment interactions in popcorn maize yield and grain quality. Spanish J. Agric. Res. 2: 85-91.

Griffing, B. (1956). Concept of general and specific combining ability in relation of diallel crossing systems. Aust. J. Biol. Sci.9 463-493.

Gözübenli, H. and Ö. Konuskan (2010). Nitrogen dose and plant density effects on popcorn grain yield. African J. of Biotechnology, 9: 3828-3832.

Halluer, A.R. (1994). Specialty Corns. Department of Agronomy, Iowa State University, Ames, Iowa.

Hallauer, A.R., M.J. Carena and J.B. Miranda Filho (2010). Quantitative Genetics in Maize Breeding. Springer, New York

Jele, P., J. Derera and M. Siwela (2014). Assessment of Australian J. Crop Sci. 8:831-839.

Junior , J. A.S.R., D.A. Cazetta, J.C. Barbosa and D.F. Filho (2013). Popping expansion and yield responses of popcorn cultivars under different row spacing and plant population. Pesq. Agropec. Bras. Brasilia, 48:1538-1545.

Larish, L., L. Band and J.L. brewbaker (1999). Diallel analysis of temperate and tropical popcorn. Maydica, 44: 279284

Li, Y.L., Y.B. Dong, S.Z. Niu and D.Q. Cui (2007). QTL for popping characteristics in popcorn. Plant Breeding 126: 509-514.

Lin, Y.E. and R.C. Anantheswaran (1988). Studies on popping of popcorn in a microwave oven. J. Food Sci. 53:17-46.

Mosa, H.E., A.A. Motawei, M.A.G. Khalil, I.A.I. El-Gazzar, M.A.A. Hassan, S.M. Abo El-Haress and Yosra A. Galal (2019). Selection of new popcorn hybrids under two plant densities. Egypt. J. Plant Breed. 23(4):653665.

Miranda, G.V., L.V. Souza, J.C.C. Galvao and L.J.M. Guimaräes (2008). Genetic variability and heterotic groups of Brazilian popcorn populations. Euphytica, 159: 123-132.

Oliveira, G.H.F., C.B. Amaral, L.T.M. Revolti, R. Buzinaro and G.V. Moro (2019). Genetic variability in popcorn synthetic population. Acta Scientiarum Agron. 41:29.

Öz, A. and H. Kapar (2011). Determination of grain yield, popcorn genotypes. Turkish J. of field crops, 16: 233238 popping ability of new tropical popcorn hybrids. some yield and quality traits of promising hybrid

Pajic, Z., U. Erić, J. Srdić, S.M. Drinić and M. Filipović (2008). Popping volume and grain yield in diallel set of popcorn inbred lines. Genetica, 40: 249 -260.

Pereira, M.G. and A.T. Amaral Junior (2001). Estimation of genetic components in popcorn based on the nested design. Crop Breeding and Applied biotechnology, 1: 3-10.

Quinn, Sr. P.V., D.C. Hong and J.A. Both (2005). Increasing the size of a piece of popcorn. Physica A. 353: 637648.

Rangel, R.M., A.T. Amaral Júnior, C.A. Scapim, S.P. Freitas Júnior and M.G. Pereira (2008). Genetic parameters in parents and hybrids of circulant diallel in popcorn. Genet. Mol. Res. 7: 1020-1030.

Sezer, I. and S. Yanbeyi (1997). Plant density and nitrogen fertilizer effects on grain yield, yield components and some plant characters of popcorn in Carsamba plain. Turkey 2. Field Corps Congree, 22-25. September Samsun, (in Turkish). pp. 128-133.

Silva, V.Q.R., A.T. Amaral Júnior, L.S.A Gonçalves, S.P. Freitas Júnior, L.S. Candido, C. Vittorazzi, L.M. Moterle, R.A. Vieira and C.A. Scapim (2010). Combining ability of tropical and temperate inbred lines of popcorn. Genet. Mol. Res. 9: 1742-1750

Song, A., S.R. Eckhoff, M. Paulsen and J.B. Litchfield (1991). Effects of kernel size and genotype on popcorn popping volume and number of unpopped kernels. Cereal Chemistry 68: 464-467.

Steel, R.G.D. and J.H. Torrie (1980). Principles and Procedures of Statistic. A Biomertrical Approach. 2 nd Ed. Mc Graw Hill, N.Y., USA.

Ülger, A.C. (1998). The effects of nitrogen doses and intra row spacing on grain yield and some agronomical characters of popcorn (Zea mays everta Sturt). J. Agric. Fac. C.U. 13:155-164.

Vijayabharathi, A., C.R. Anandakumar and R.P. Gnanamalar (2009). Analysis of correlations and path effects for popping expansion in popcorn (Zea mays everta). Electronic J.of Plant Breeding, 1:60-64

Ziegler, K.E. (2001). Popcorn. Pages 199-234 in: Specialty Corn A.R. Hallauer, ed. CRC Press: Boca Raton, FL USA.

Ziegler, K.E., R.B. Ashman, G.M. White and D.B. Wysong (1988). Popcorn production and marketing. Iowa, Coop. Ext. Serv. Publ. NCH. 5,1.

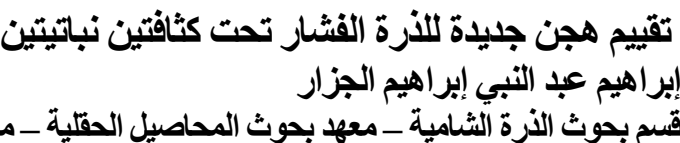

قَم بحوث الذرة الثثامية _ معهد بحوث المحاصيل الحقلية ـ مركز البحوث الزراعية

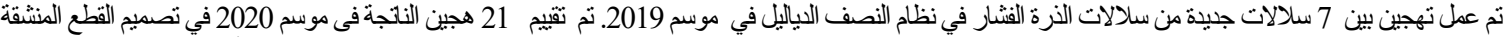

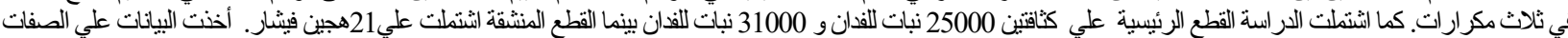

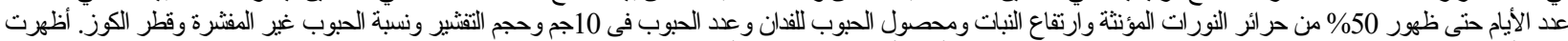

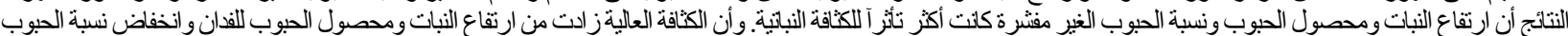

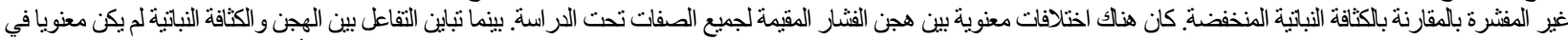

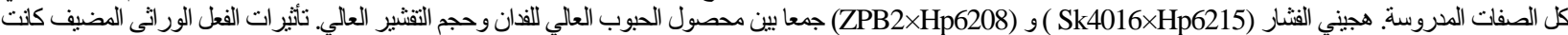

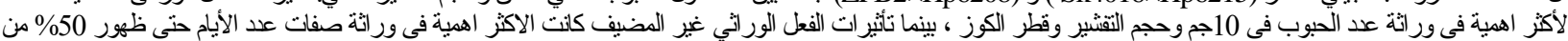

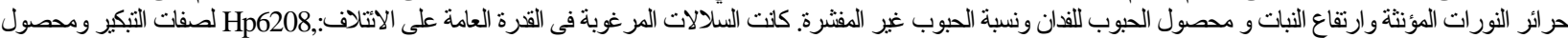

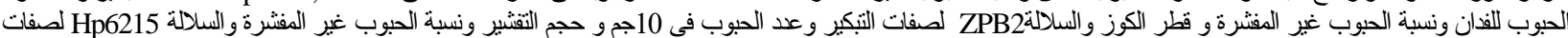

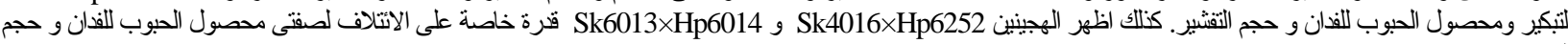

